\title{
WHEN INSOLVENCY AND RESTRUCTURING LAW SUPERCEDES CONTRACT
}

\author{
DON GREENFIELD, ${ }^{*}$ PAT MAGUiRe, ${ }^{* *}$ \\ DAVID SPENCER, ${ }^{* * *}$ AND KEN LENZ ${ }^{* * * *}$
}

\begin{abstract}
The impact of counterparty insolvency on contracts has become an area of concern for those in the energy industry. The Bankruptcy and Insolvency Act, Companies' Creditors Arrangement Act, Alberta Business Corporations Act, and Canada Business Corporations Act are all statutes that override or diminish strict contractual rights. This article examines six ways in which these pieces of legislation accomplish this: (1) restructuring proceedings; (2) stays of proceedings; (3) replacement and default clauses; (4) disclaimers of contracts; (5) assignment of contracts without the consent of the solvent counterparty; and (6) plans of arrangement. Public policy considerations support this legal framework, but it has a significant impact on the solvent party when trying to achieve restructuring or insolvency objectives and preserving legitimate bargains. Therefore, it is crucial for energy law practitioners to understand these policy considerations and this area of law to be able to properly advise clients of the inherent risks and options available.
\end{abstract}

\section{TABLE OF CONTENTS}

I. INTRODUCTION . . . . . . . . . . . . . . . . . . . . . . . . 350

II. Restructuring Proceedings Generally . . . . . . . . . . . 351

A. THE BANKRUPTCY AND INSOLVENCY ACT:

RECEIVERSHIP, BANKRUPTCY, AND PROPOSALS . . . . . . . . 351

B. THE COMPANIES' CREDITORS ARRANGEMENT ACT:

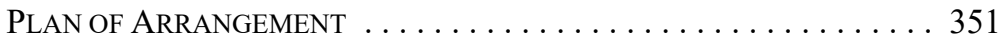

C. The Business Corporations Legislation:

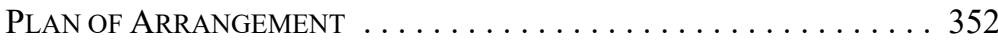

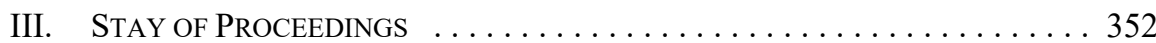

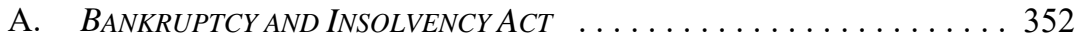

B. Companies' CREDitors ARRANGEMENT ACT . . . . . . . . . 354

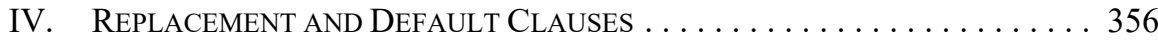

V. DiSClAIMER OF CONTRACTS . . . . . . . . . . . . . . . . . . . . . 359

VI. ASSIGNMENT OF CONTRACTS WiTHOUT THE CONSENT

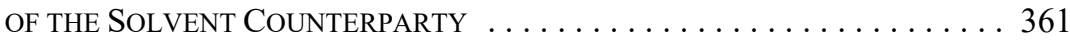

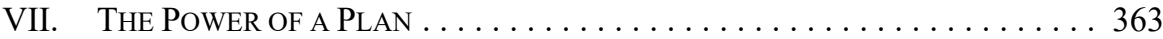

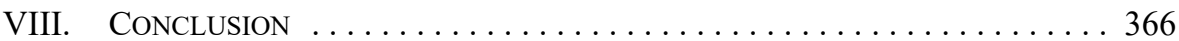

* Don Greenfield, Q.C. is a Partner at Bennett Jones LLP in Calgary, whose practice includes private M\&A and project development as well as Investment Canada Act matters.

** Pat Maguire is a Partner at Bennett Jones LLP and Co-Head of its Corporate Department. Pat's practice includes most aspects of energy transactions and project development.

*** David Spencer's business law practice at Bennett Jones LLP in Calgary includes mergers and acquisitions, corporate finance, including IPOs, and corporate governance advice for boards of directors.

***** Co-head of Bennett Jones LLP's litigation department, Kenneth Lenz, Q.C. focuses his practice on insolvency and restructuring matters. 


\section{INTRODUCTION}

The goal of bankruptcy pursuant to the Bankruptcy and Insolvency Act ${ }^{1}$ is to enable fair and orderly distribution of an insolvent person's property amongst that person's creditors. ${ }^{2}$ The Companies' Creditors Arrangement $\mathrm{Act}^{3}$ aims to provide a means for companies to reorganize their affairs and continue to operate as a going concern. The plan of arrangement provisions in the Alberta Business Corporations Act ${ }^{4}$ and the Canada Business Corporations $A c t^{5}$ are intended to force resolutions to certain corporate challenges that are impractical to resolve otherwise. All of these statutes overrule or otherwise diminish strict contractual rights, often to the surprise of corporate counsel. This article sets out some of the common ways this is accomplished within the framework of the statutes.

There are six sections to this article: (1) Restructuring Proceedings, which offers a highlevel view of the legal frameworks available to restructure an insolvent business; (2) Stay of Proceedings, which discusses various elements related to how stays of proceedings function; (3) Replacement and Default Clauses, which discusses how these clauses operate in the context of insolvency proceedings; (4) Disclaimer of Contracts, which discusses companies' rights to disclaim contracts in the context of insolvency proceedings; (5) Assignment of Contracts Without the Consent of the Solvent Counterparty, which discusses companies' rights to assign contracts in the context of insolvency proceedings; and (6) The Power of a Plan, which discusses the use of the plan of arrangement sections found in corporate law statues in Canada to avoid certain contractual provisions. Generally, this article reveals how contractual rights are often secondary to the larger policy goals of insolvency and reorganization legislation, which are to maximize realization or the likelihood that a company will continue to operate as a going concern with all of the economic, social, and policy benefits that entails.

These policy considerations find contract law bending to insolvency and restructuring legislation in a number of respects material to the energy law practitioner. At the most fundamental legal level, the provisions of the BIA and the CCAA take precedence over contractual rights because they fall within federal jurisdiction pursuant to sections 91 and 92 of the Constitution Act, 1867. ${ }^{6}$ A most basic constitutional principle in Canada is that legislation affecting areas of provincial responsibility must, in the event of a conflict, give way to legislation in areas of federal responsibility. ${ }^{7}$ Contract law, which falls into the broad category of the provincial areas of property and civil rights, is unenforceable to the extent that there is a conflict with federal insolvency legislation. ${ }^{8}$

RSC 1985, c B-3 [BIA].

Geoffrey H Dabbs, "General Overview of Bankruptcy and Insolvency Law" (2011) Continuing Legal Education Society of British Columbia Working Paper No 1.1 at 3, online: < https://www.cle.bc. ca/PracticePoints/BUS/11-GeneralOverview.pdf $>$.

RSC 1985, c C-36 [CCAA].

RSA 2000, c B-9 [ABCA].

RSC 1985, c C-44 [CBCA].

(UK), 30 \& 31 Vict, c 3, ss 91-92, reprinted in RSC 1985, Appendix II, No 5.

This principle is otherwise known as the doctrine of paramountcy. As Justice Major explained in Rothmans, Benson \& Hedges Inc v Saskatchewan, 2005 SCC 13, [2005] 1 SCR 188 at para 11, "[t]he doctrine of federal legislative paramountcy dictates that where there is an inconsistency between validly enacted but overlapping provincial and federal legislation, the provincial legislation is inoperative to the extent of the inconsistency." 
Before turning to the larger concepts that affect contractual rights, it is useful to point out that certain commonly used contractual clauses are usually not enforceable: namely, clauses that make bankruptcy or insolvency a default under a contract. This has long been the law but was recently codified in the BIA, section $84.2(1)$ :

84.2(1) Certain rights limited — No person may terminate or amend — or claim an accelerated payment or forfeiture of the term under - any agreement, including a security agreement, with a bankrupt individual by reason only of the individual's bankruptcy or insolvency. ${ }^{9}$

While there are some exceptions to this rule contained in further subparagraphs of this section of the $B I A$, a more important point is that the rule is actually of broader application, since virtually every insolvency proceeding involves a stay of any action enforcing rights based on an insolvency default.

\section{Restructuring Proceedings Generally}

\section{A. THE BANKRUPTCY AND INSOLVENCY ACT: RECEIVERSHIP, BANKRUPTCY, AND PROPOSALS}

There are three primary procedures under the BIA. The first two are creditor controlled: receivership and bankruptcy; the third is the proposal procedure, which is debtor controlled. The goal of bankruptcy and receivership is to liquidate the assets of an insolvent person or company and to maximize the return to creditors. In furtherance of this goal, receivers or trustees are given a number of powers to terminate or perform contracts, renegotiate terms, sell assets, and perform other functions.

The third procedure is the BIA proposal provisions, ${ }^{10}$ which allow a debtor to make a proposal to creditors that is voted on and either approved or disapproved, similar to the $C C A A$. If a proposal is approved by the required majority in number and two thirds in value ${ }^{11}$ it becomes a legally binding contract between the debtor and all its creditors. If a proposal is not approved, the debtor is declared bankrupt and a trustee is appointed who oversees the liquidation of its assets. ${ }^{12}$

\section{B. The Companies' Creditors ArRANGEMENT ACt: Plan OF ARRANGEMENT}

The CCAA allows an insolvent company to propose a plan of arrangement to creditors to restructure its affairs, ultimately with a view to carrying on as a going concern. There are a number of key differences between BIA proposals and plans of arrangement under the CCAA, including the scale and the flexibility afforded by each. The CCAA can only be used by companies with more than $\$ 5$ million of outstanding debt, ${ }^{13}$ it is intended to be used for larger-scale reorganizations. However, the CCAA allows greater flexibility regarding dealing

BIA, supra note $1, \mathrm{~s} 84.2(1)$.

Ibid, Part III.

Ibid, s 54(2)(d).

Ibid, s 57.

CCAA, supra note 3 , s 3(1). 
with complex corporate structures or contractual arrangements. If a CCAA plan is not approved, then typically a secured creditor would apply for an order lifting the stay of proceedings so that they may realize upon their security. However, that is not automatic as it would be in a BIA proposal, and sometimes a second plan is put forth and is successful.

\section{THE BUSINESS CORPORATIONS LEGISLATION: Plan of ArRangement}

Insolvency legislation is not the only legal framework available to reorganize a corporation. In some instances, the reorganization and arrangement provisions of the relevant business corporations legislation may serve as a useful alternative. A simple exchange of securities under the $A B C A$, for example, whereby creditors receive new securities in exchange for existing debt, may accomplish what is needed to return the company to a financially viable position, though there is some doubt about whether this can be accomplished under the $A B C A$ except in conjunction with a federal statute. ${ }^{14}$

\section{Stay of Proceedings}

In almost every formal insolvency proceeding, the court grants an order preventing or staying proceedings against the debtor company. The purpose of the stay is, in the case of receivership or bankruptcy, to allow an orderly disposition of assets. In the case of a $B I A$ proposal or CCAA proceedings, the purpose of the stay is to allow the company time to prepare a proposal or a plan of arrangement without the day-to-day pressure of creditor demands. The scope of the stay is the critical issue and will determine what rights can be enforced. Unfortunately, receivership, BIA proposal proceedings, and CCAA proceedings have different language for the stay, and while they are broadly similar, reference needs to be made in each case to the applicable provisions. It is also worth noting that stays of proceedings have been granted under CBCA proceedings. ${ }^{15}$ However, the scope of a stay is arguably limited to situations where it is not required to preserve solvency, as set out by Justice Jones in the recent decision of 9171665 Canada Ltd. $(\operatorname{Re}) .^{16}$

\section{A. BANKRUPTCY AND INSOLVENCY ACT}

Under section 69(1) of the BIA, a stay of proceedings begins as soon as a debtor either files a notice of intention with the official receiver or files a proposal with a trustee with the Office of the Superintendent of Bankruptcy. ${ }^{17}$ This stay binds both secured and unsecured creditors. The first stay of proceedings is triggered by filing a notice of intention and lasts for a period of 30 days; it may be extended in 45-day increments for a maximum period of six months. ${ }^{18} \mathrm{~A}$ further stay of proceedings is triggered upon the filing of a proposal, and

14 Frank R Foran \& Terrence M Warner, "Reorganizing the Insolvent Oil and Gas Corporation: The Courts and Fairness" (1990) 28:1 Alta L Rev 132 at 133.

15 See 45133541 Canada inc (Arrangement relatif à), 2009 QCCS 6444, 2009 QCCS 6444 (CanLII); 8440522 Canada Inc (Re), 2013 ONSC 2509, 16 BLR (5th) 33; Essar Steel Canada Inc (Re), 2014 ONSC 4285, 2014 ONSC 4285 (CanLII).

2015 ABQB 633, 617 AR 30 [Connacher].

BIA, supra note 1 .

Ibid, ss 50.4(8)-(9). 
continues until the proposal succeeds and the trustee is discharged or the proposal fails and the debtor becomes bankrupt.

In a receivership, the stay of proceedings is set out in a template receivership order. The Alberta template order provides in paragraphs 8 and 9:

\section{NO PROCEEDINGS AGAINST THE DEBTOR OR THE PROPERTY}

8. No proceeding against or in respect of the Debtor or the Property shall be commenced or continued except with the written consent of the Receiver or with leave of this Court and any and all Proceedings currently under way against or in respect of the Debtor or the Property are hereby stayed and suspended pending further Order of this Court, provided, however, that nothing in this Order shall: (i) prevent any Person from commencing a proceeding regarding a claim that might otherwise become barred by statute or an existing agreement if such proceeding is not commenced before the expiration of the stay provided by this paragraph 8; and (ii) affect a Regulatory Body's investigation in respect of the debtor or an action, suit or proceeding that is taken in respect of the debtor by or before the Regulatory Body, other than the enforcement of a payment order by the Regulatory Body or the Court. "Regulatory Body" means a person or body that has powers, duties or functions relating to the enforcement or administration of an Act of Parliament or of the legislature of a province.

\section{NO EXERCISE OF RIGHTS OF REMEDIES}

9. All rights and remedies (including, without limitation, set-off rights) against the Debtor, the Receiver, or affecting the Property, are hereby stayed and suspended except with the written consent of the Receiver or leave of this Court, provided however ... that nothing in this paragraph shall (i) empower the Receiver or the Debtor to carry on any business which the Debtor is not lawfully entitled to carry on, (ii) exempt the Receiver or the Debtor from compliance with statutory or regulatory provisions relating to health, safety or the environment, (iii) prevent the filing of any registration to preserve or perfect a security interest, or (iv) prevent the registration of a claim for lien. ${ }^{19}$

The stay is broad and precludes any remedies under existing agreements. Counterparties must continue to provide goods or services in accordance with the existing agreements. The stay of proceedings is in place until the receiver completes its mandate, which is usually to sell assets of the insolvent entity and distribute the proceeds in accordance with the provincial priority scheme.

To lift a stay under the BIA or a receivership order, a creditor may apply to a court for a declaration that the stay of proceedings no longer applies to that creditor, or is lifted for a specific purpose. Typically, the applicant must convince the court that the stay causes the applicant undue hardship and that the applicant is likely to be significantly prejudiced, or provide some other equitable grounds. ${ }^{20}$ There is a high bar to lift a stay of proceedings, but it is done in appropriate cases. 


\section{B. Companies' Creditors ArRANGEMENT ACT}

As discussed earlier, to initiate proceedings under the CCAA, a company must be insolvent, or on the eve of insolvency, and must have outstanding liabilities of $\$ 5$ million or more. The debtor company brings an initial order application for a stay of proceedings which the court grants for an initial 30 day period. ${ }^{21}$ As with receivership, there is now a template order which provides in paragraphs $13-19$ as follows:

\section{NO PROCEEDINGS AGAINST THE APPLICANT OR THE PROPERTY}

13. Until and including [DATE - MAX. 30 DAYS], or such later date as this Court may order (the "Stay Period"), no proceeding or enforcement process in any court (each, a "Proceeding") shall be commenced or continued against or in respect of the Applicant or the Monitor, or affecting the Business or the Property, except with leave of this Court, and any and all Proceedings currently under way against or in respect of the Applicant or affecting the Business or the Property are hereby stayed and suspended pending further order of this Court.

\section{NO EXERCISE OF RIGHTS OR REMEDIES}

14. During the Stay Period, all rights and remedies of any individual, firm, corporation, governmental body or agency, or any other entities (all of the foregoing, collectively being "Persons" and each being a "Person"), whether judicial or extra-judicial, statutory or non-statutory against or in respect of the Applicant or the Monitor, or affecting the Business or the Property, are hereby stayed and suspended and shall not be commenced, proceeded with or continued except with leave of this Court, provided that nothing in this Order shall:

(a) empower the Applicant to carry on any business which the Applicant is not lawfully entitled to carry on;

(b) affect such investigations, actions, suits or proceedings by a regulatory body as are permitted by section 11.1 of the CCAA;

(c) prevent the filing of any registration to preserve or perfect a security interest; or

(d) prevent the registration of a claim for lien.

15. Nothing in this Order shall prevent any party from taking an action against the Applicant where such an action must be taken in order to comply with statutory time limitations in order to preserve their rights at law, provided that no further steps shall be taken by such party except in accordance with the other provisions of this Order, and notice in writing of such action be given to the Monitor at the first available opportunity. 


\section{NO INTERFERENCE WITH RIGHTS}

16. During the Stay Period, no person shall accelerate, suspend, discontinue, fail to honour, alter, interfere with, repudiate, terminate or cease to perform any right, renewal right, contract, agreement, licence or permit in favour of or held by the Applicant, except with the written consent of the Applicant and the Monitor, or leave of this Court.

\section{CONTINUATION OF SERVICES}

17. During the Stay Period, all persons having:

(a) statutory or regulatory mandates for the supply of goods and/or services; or

(b) oral or written agreements or arrangements with the Applicant, including without limitation all computer software, communication and other data services, centralized banking services, payroll services, insurance, transportation, services, utility or other services to the Business or the Applicant

are hereby restrained until further Order of this Court from discontinuing, altering, interfering with, suspending or terminating the supply of such goods or services as may be required by the Applicant or exercising any other remedy provided under such agreements or arrangements. The Applicant shall be entitled to the continued use of its current premises, telephone numbers, facsimile numbers, internet addresses and domain names, provided in each case that the usual prices or charges for all such goods or services received after the date of this Order are paid by the Applicant in accordance with the payment practices of the Applicant, or such other practices as may be agreed upon by the supplier or service provider and each of the Applicant and the Monitor, or as may be ordered by this Court. Nothing in this Order has the effect of prohibiting a person from requiring immediate payment for goods, services, use of leased or licensed property or other valuable consideration provided on or after the date of this Order.

\section{NO OBLIGATION TO ADVANCE MONEY OR EXTEND CREDIT}

18. Notwithstanding anything else contained in this Order, no creditor of the Applicant shall be under any obligation on or after the date of this Order to advance or re-advance any monies or otherwise extend any credit to the Applicant.

\section{PROCEEDINGS AGAINST DIRECTORS AND OFFICERS}

19. During the Stay Period, and except as permitted by subsection 11.03(2) of the CCAA and paragraph 15 of this Order, no Proceeding may be commenced or continued against any of the former, current or future directors or officers of the Applicant with respect to any claim against the directors or officers that arose before the date hereof and that relates to any obligations of the Applicant whereby the directors or officers are alleged under any law to be liable in their capacity as directors or officers for the payment or performance of such obligations, until a compromise or arrangement in respect 
of the Applicant, if one is filed, is sanctioned by this Court or is refused by the creditors of the Applicant or this Court. ${ }^{22}$

Codified in the CCAA and set out in the standard order, a stay of proceedings under the CCAA cannot prohibit a person from requiring immediate payment for goods and services provided after the order is made (also known as post-filing claims) or require the further advance of money or credit. ${ }^{23}$ Pre-filing claims are stayed and will be dealt with under a plan of arrangement or distribution of sales proceeds in the priority set out in the CCAA, the $B I A$, and other legislation. Set-off is specifically allowed under the provisions of the BIA and $C C A A$ in respect of mutual obligations owed. ${ }^{24}$ The court may grant extensions to the stay as it deems appropriate under the CCAA. Similar to the BIA, it is difficult to lift a stay under the CCAA, but the court will do so in appropriate cases of undue hardship, prejudice, or some other equitable ground.

\section{MEANING OF PROCEEDINGS}

The stay granted under the CCAA applies to "proceedings." 25 While the term "proceedings" is clearly broad enough to prevent the commencement of judicial or administrative remedies, the extent to which it restrains contractual rights is an interesting question that has received some judicial attention. The jurisprudence is clear that the term "proceeding" is meant to be interpreted broadly in order to maximize the ability of the court to prevent creditors from taking actions that will increase the financial stress on a debtor corporation while a plan of arrangement is being developed..$^{26}$ The court may restrain actions by parties who are not, strictly speaking, creditors of the debtor company.

In Meridian Developments, Justice Wachowich noted that " $[\mathrm{t}]$ o narrow the interpretation of 'proceeding' could lessen the ability of a court to restrain a creditor from acting to prejudice an eventual arrangement in the interim when other [creditors] are being consulted." ${ }^{27} \mathrm{He}$ added that in the absence of qualifying words after "proceeding," such as proceedings "which involve either a court or court official" or proceedings "before a court or tribunal," Parliament intended for "proceeding" to apply to more than legal proceedings. ${ }^{28}$ Most significantly, in virtually every case, default provisions based on insolvency or bankruptcy are stayed and therefore unenforceable.

\section{RePlacement and Default Clauses}

An example of the stay of proceedings applied to the oil and gas context arises in attempts to change the operator of an operation, upon the operator becoming insolvent. The Canadian Association of Petroleum Landmen (CAPL) industry standard operating procedure (currently

Alberta Court of Queen's Bench, "Alberta Template CCAA Initial Order" (December 2012) at paras 13-19, online: $<$ https://albertacourts.ca/court-of-queens-bench/commercial-practice $>$ [emphasis added]. CCAA, supra note 3 , s 11.01 .

Ibid, s 21; BIA, supra note 1, s 97(3).

CCAA, ibid.

Meridian Developments Inc v Toronto Dominion Bank (1984), 11 DLR (4th) 576 at 584 (Alta QB) [Meridian Developments].

Ibid.

Ibid. 
the 2015 CAPL Operating Procedure $)^{29}$ provides that non-operators are allowed to immediately replace a bankrupt or insolvent operator as follows:

The Parties acknowledge that the Operator's ability to fulfill its duties and obligations for the Parties' benefit is largely dependent on its ongoing financial viability and that the Operator may not seek relief at law, in equity or under the Regulations to prevent its replacement in accordance with this Subclause. The Operator will be replaced immediately after service of notice from any Non-Operator to the other Parties to such effect if:

(a) the Operator becomes bankrupt or insolvent, commits or suffers any act of bankruptcy or insolvency, is placed in receivership or seeks debtor relief protection under applicable legislation (including the Bankruptcy and Insolvency Act (Canada) and the Companies' Creditors Arrangement Act (Canada)), and it will be deemed to be insolvent for this purpose if it is unable to pay its debts as they fall due in the usual course of business or if it does not have sufficient assets to satisfy its cumulative liabilities in full. ${ }^{30}$

The question is whether this is enforceable in the face of a stay of proceedings.

Historically, the law has been that leave of the court is required for a non-operator to invoke this clause against an insolvent operator under a stay of proceedings. This exact scenario was the subject of Norcen Energy Resources Ltd. v. Oakwood Petroleums Ltd. in 1988. ${ }^{31}$ Norcen Energy Resources Ltd. (Norcen) was seeking to have Oakwood Petroleums Ltd. (Oakwood) removed as operator of certain oil and gas properties that Norcen had a working interest in. Norcen and Oakwood had an agreement, incorporating provisions of the 1981 CAPL joint operating agreement, which had provisions similar to those in the 2015 $C A P L$ for the replacement of the operator should the operator become insolvent. Oakwood had previously been granted a stay of proceedings under the CCAA, and Norcen argued that the Court had no jurisdiction to restrain Norcen's actions under this clause in its stay order. ${ }^{32}$ It argued further that if section 11 of the CCAA could be interpreted that broadly, then it was unconstitutional in that it purported to affect contractual rights of third parties. ${ }^{33}$ To Norcen's constitutional argument, Justice Forsyth responded:

Accordingly, if promoting the continuance of insolvent companies is constitutionally valid as insolvency legislation, it follows that a stay which happens to affect some non-creditors in pursuit of that end is valid. Surely a necessary part of promoting the continuance of a company is to give that company some time to stop and gather its faculties without interference from affected parties for a brief period of time. In my opinion, the distinction between creditors' contractual rights and the contractual rights of non-creditor third parties that Norcen asks me to draw is not a helpful one in these circumstances. Continuance of a company involves more than consideration of creditor claims. For that reason, I am of the opinion that s. 11 of the C.C.A.A. can validly be used to interfere with some other contractual relationships in circumstances which threaten a company's existence. ${ }^{34}$

Canadian Association of Petroleum Landmen, 2015 CAPL Operating Procedure (Calgary: CAPL, 2015) online: <landman.ca/resources/forms-store/2015-capl-operating-procedure/> [2015 CAPL].

Ibid, s 2.02(A).

(1988), 63 Alta LR (2d) 361 (QB) [Norcen Energy].

Ibid at 366 .

Ibid.

Ibid at 376 [emphasis added]. 
Similarly, default remedies for a party's failure to pay amounts to a counterparty in a typical oil and gas operating contract (for example, see section 5.05(B) of the 2015 CAPL) ) $^{35}$ are likely not enforceable when the defaulting party is the subject of a stay of proceedings. This may be to the detriment of a minority owner who wants to bring about a change of operatorship against a resisting operator who is also the majority owner, "even where the operator is in persistent default under the terms of the agreement," and especially after the operator has declared itself insolvent. ${ }^{36}$

In 2016, the Alberta Court of Queen's Bench cast some doubt as to whether the law as set out in Norcen Energy applies in all cases. In Bank of Montreal v. Bumper Development Corporation Ltd., ${ }^{37}$ Eagle Energy Inc. (Eagle) and Bumper Development Corporation Ltd. (Bumper) were parties to a joint operating agreement with respect to certain wells and a battery facility. The joint operating agreement incorporated an earlier version of the 2015 $C A P L$, with the identical immediate replacement clause. After Bumper filed under the BIA, a receiver was appointed over Bumper in order to protect and realize upon Bumper's assets and distribute the proceeds. ${ }^{38}$ A stay of proceedings was in place to restrain all rights and remedies against Bumper. ${ }^{39}$ The receiver conducted a sale of Bumper's Assets. ${ }^{40}$ Both Eagle and Forent Energy Ltd. (Forent) submitted bids. In the interim, Eagle notified the receiver that it intended to assume operatorship and the parties had discussions regarding the terms of the sale. Prior to a bid being accepted, the receiver indicated to Eagle that it would not entertain any offer purporting to convey operatorship of Bumper's assets to anyone other than Eagle. The receiver later indicated to the Court that operatorship would not be part of any sale. ${ }^{41}$

Forent was the successful bidder and the receiver successfully applied for approval of the sale of Bumper's interest to Forent and for a vesting of the assets subject to later determination of Eagle's application to assume operatorship, which Forent opposed. ${ }^{42}$ In the course of finding for Eagle, Justice Macleod wrote:

Had Eagle pursued its right to be Operator at the time of the granting of the Receivership Order or soon thereafter, I can think of no reason why this Court would not have acceded to Eagle's request to lift the stay and grant a declaration with respect to both the wells and the Battery.

The stay was granted incidental to the appointment of the Receiver to permit for orderly realization and distribution. Eagle's right to operate, however, arises under a contract which pre-dates the receivership. Also, there is no reason to interfere with the contractual rights of Eagle which are not subject to the security of Bumper's creditors. ${ }^{43}$

2015 CAPL, supra note 29, cl 5.05(B).

Nigel Bankes, "Co-Ownership is a Messy Business (Even With an Operating Agreement)" (15 February 2009), ABlawg (blog), online: <ablawg.ca/2009/02/15/co-ownership-is-a-messy-business-even-with-anoperating-agreement/>. 2016 ABQB 363, 38 CBR (6th) 118.

Ibid at para 2.

Ibid at para 9 .

Ibid at para 10 .

Ibid at para 13

Ibid at para 14 .

Ibid at paras 18-19 [emphasis added]. 
Justice Macleod explicitly differentiated this case from Norcen Energy, highlighting that Norcen Energy dealt with section 11 of the CCAA, which gives broad powers to the court in situations where arrangements can be developed to save insolvent companies. "Here, the issue is not Bumper's survival but the realization on its assets," wrote Justice Macleod. ${ }^{45}$ To deprive Eagle of operatorship "would be tantamount to appropriating Eagle's right for the benefit of Bumper's creditors." "46 The Receiver and others were also directed to transmit all accounts and licences which were reasonably necessary for Eagle to assume operatorship. ${ }^{47}$

This case is of course of interest to lenders, as operatorship often has significant value, which a secured lender wants to preserve and realize upon in enforcement proceedings. But the case is equally important to others involved in joint ventures who often will want to replace an operator upon it being placed into receivership.

\section{Disclaimer of Contracts}

Another mechanism by which Canadian insolvency legislation can alter the contractual obligations of a debtor company to its creditors and non-creditors is through the disclaimer provisions of the CCAA and the BIA. Section 32(1) of the CCAA states:

[A] debtor company may - on notice given in the prescribed form and manner to the other parties to the agreement and the monitor - disclaim or resiliate any agreement to which the company is a party on the day on which proceedings commence under this Act. The company may not give notice unless the monitor approves the proposed disclaimer or resiliation. ${ }^{48}$

These provisions were enacted by Parliament in 2009 to codify the debtor's ability to disclaim contracts. They allow the debtor to terminate, or "disclaim" in insolvency parlance, contracts if such termination enhances value or facilitates the restructuring of the debtor company, despite some harm to the counterparties to the contract. If a disclaimer is approved, either by the monitor or by the court, the counterparty can make a claim in the insolvency proceeding for damages resulting from the disclaimer as an unsecured creditor.

Section 65.11(1) of the BIA provides substantially similar provisions for debtors who initiate proceedings under the BIA proposal provisions. ${ }^{49}$ The process is also similar under both statutes. Once the debtor proposes to disclaim the contract, the monitor either grants or refuses consent. If the monitor approves, the disclaimer takes effect 30 days after the counterparties to the contract receive notice, unless a counterparty applies to the court to challenge the disclaimer. If the monitor does not approve, the debtor must, on notice to the monitor and counterparties, apply for court approval of the disclaimer. ${ }^{50}$

In deciding to approve a disclaimer, a court must consider the following factors: (a) whether the monitor approved the proposed disclaimer; (b) whether a disclaimer will enhance

Ibid at para 20 .

Ibid.

Ibid at para 23

Ibid at para 27.

CCAA, supra note $3, \mathrm{~s} 32(1)$.

BIA, supra note $1, \mathrm{~s} 65.11(1)$.

Ibid, s 65.11; CCAA, supra note 3, s 32 . 
the prospects of a viable compromise or arrangement; and (c) whether a disclaimer will likely cause significant financial hardship to a counterparty to the agreement ${ }^{51}$ It is fair to say that these factors are strongly in favour of the ability to disclaim contracts. It will be rare that a disclaimer is not allowed, subject to certain cases where it is not permitted for policy or other reasons.

In the recent, unreported decision of Credit Suisse AG v. Southern Pacific Resource Corp., the applicant, Altex Energy Ltd. (Altex) was a trade creditor of Southern Pacific Resource Corp. (Southern Pacific). ${ }^{52}$ After Southern Pacific applied for a stay of proceedings under the CCAA, it issued a notice to disclaim a terminal construction and rail services agreement. The disclaimer was not opposed by any counterparty and Southern Pacific ceased using Altex's services at the date of the disclaimer. Altex argued in its application that it was entitled to payment for the 30 day period from the date of the notice of disclaimer. Southern Pacific said the disclaimer took immediate effect. Justice Romaine held that the counterparty to the disclaimed contract was not entitled to payment after the date of the disclaimer notice, arguably contrary to the plain wording of the section. ${ }^{53}$

For non-insolvency lawyers, the 8 March 2016 United States Bankruptcy Court decision of Re Sabine Oil \& Gas Corp. created much concern. ${ }^{54}$ In that case, the Court ruled that the bankrupt could terminate a midstream gathering agreement because the agreement did not create an interest in land. In the United States, as in Canada, agreements that create interests in land cannot be unilaterally terminated and run with the land notwithstanding bankruptcy. This has long been the law and is an important consideration when drafting many agreements, like rights of first refusal (ROFRs) or gross overriding royalties. ROFRs may be interests in land ${ }^{55}$ and as a result, such an interest should not be terminable in an insolvency. Similarly, gross overriding (and similar) royalties may also be held to be interests in land and thus survive the royalty payor's insolvency. ${ }^{56}$

As a result of the resilience provided by an interest in land, parties may be tempted to "bankruptcy proof" their agreements by purporting to embed within them interests in land. There are a few challenges to this strategy. Notwithstanding the emphasis in Dynex of the parties' intention to create an interest in land, an express declaration of such intention is not necessarily sufficient to make it so. ${ }^{57}$ As one celebrated author notes in his commentary to Walter Energy Canada Holdings, Inc. (Re) ${ }^{58}$ an insolvency case where a royalty was determined not to be an interest in land, determination of this intention "still requires assessment of the intentions of the parties as revealed in the language used in the document and any relevant surrounding commercial circumstances." 59

CCAA, ibid, s 32(4).

(28 October 2016), Calgary 1501-05908 (Alta QB).

Ibid.

550 BR 59 (NY Bankr 2016) [Sabine].

Koppe v Garneau Lofts Inc, 2008 ABQB 354, 455 AR 76; Paul M Perell, "Options, Rights of Repurchase and Rights of First Refusal as Contracts and as Interests in Land" (1991) 70:1 Can Bar Rev 1.

Bank of Montreal v Dynex Petroleum Ltd, 2002 SCC 7, [2002] 1 SCR 146 [Dynex].

Third Eye Capital Corp v Dianor Resources Inc, 2016 ONSC 6086, 41 CBR (6th) 320.

2016 BCSC 1746, 39 CBR (6th) 292.

Nigel Bankes, "Pre-Dynex Royalty Agreements Continue to Spawn Interest in Land Litigation" (13 October 2016), ABlawg (blog), online: < https://ablawg.ca/2016/10/13/pre-dynex-royalty-agreementscontinue-to-spawn-interest-in-land-litigation/> [emphasis added]. 
Interestingly however, the 2007 amendments to the CCAA explicitly indicate only that "a lease of real property or of an immovable if the company is the lessor" is not subject to disclaimer, instead of referencing interests in land. ${ }^{60}$ That language is narrower than the historic prohibition of termination of interests in land. The authors could not locate case law considering this point, but suggest that the narrow language does not really affect the principle, which is based on the fact that one cannot undo a conveyance, as opposed to terminate a contract.

As relates to pipeline, processing, and other midstream agreements, the purported creation of an interest in land is often sought to be achieved by land dedication. While a full analysis of this issue is beyond the scope of this article, having regard for the 2007 amendments to the CCAA, Sabine, and the recent Canadian royalty cases, one might be concerned about relying on the purported creation of an interest in land in an effort to have a contract survive insolvency. A more conventional approach to credit support (that is, the prior registration of a security interest, land charge, or debenture) would seem to be the safer route where circumstances permit.

\section{Assignment of Contracts Without THE CONSENT OF THE SOlVENT COUNTERPARTy}

In 2007, the BIA was amended by the addition of section 84.1 , which allows a court, upon being satisfied that certain prerequisites are met, to grant an order assigning the rights and obligations of the bankrupt under any agreement to a purchaser, even without the consent of the counterparty to the agreement. ${ }^{61}$ An equivalent provision is in the CCAA under section 11.3. ${ }^{62}$ Although it is not expressly stated in the statutes, both sections have been held to effectively override contractual provisions requiring consent, where the court considers the withholding of consent unreasonable. ${ }^{63}$ This is not entirely new, as prior to these amendments, there were a number of cases, primarily dealing with selling valuable leases, where courts implied a reasonableness requirement into a consent provision, and did not allow a landlord to unreasonably withhold consent. ${ }^{64}$

In the insolvency context, a court's aim is to facilitate maximum value recovery for stakeholders, or preserve the entity as a going concern. Under the BIA and CCAA, courts in Canada will permit an assignment unless there are real and substantial concerns regarding the assignee or there is some other significant reason. ${ }^{65}$ The policy reasons for allowing the assignment of contracts is the facilitation of the successful and expedient restructuring of a company's financial health or the orderly liquidation of its assets, depending on the circumstances. 
Under section 84.1(4) of the BIA, courts are to consider "(a) whether the person to whom the rights and obligations are to be assigned is able to perform the obligations; and (b) whether it is appropriate to assign the rights and obligations to that person." ${ }^{\text {66 }}$ Section 11.3(3) of the CCAA directs that the court also consider whether the monitor has given consent. ${ }^{67}$ Both sections test the "appropriateness" of assigning the rights and obligations to that person and both consider whether the assignee is able to perform the obligations.

In determining the reasonableness of withholding consent to assignment, the question to be asked is whether a reasonable person would have withheld consent in the circumstances, taking account of the commercial realities of the marketplace, the economic impact of the assignment, and the financial position of the proposed assignee. ${ }^{68}$ In most cases, it will be unreasonable to withhold consent, as the counterparty is usually better off with anyone other than an insolvent debtor counterparty.

While many assignments are permitted, the courts will also refuse if the assignment does not actually help the debtor and the prejudice is significant. In Nexient Learning Inc., Re ${ }^{69}$ the Ontario Superior Court of Justice addressed its authority to authorize the assignment of a license agreement. Nexient Learning involved a motion to assign a contract from Nexient Learning Inc. and Nexient Learning Canada Inc. (collectively, Nexient) to a third party on terms that would permanently stay the right of ESI International Inc. (ESI) to exercise rights of termination that arose as a result of Nexient's insolvency. ESI was the respondent to the motion. ${ }^{70}$

The Court determined that it should exercise such authority only in circumstances where it is important to the reorganization process, notwithstanding any provisions to the contrary within the relevant agreement. ${ }^{71}$ Whether or not authorization is important to the reorganization process requires consideration of the purpose of the CCAA or the BIA and the effect on the parties' contractual rights. In Nexient Learning the Court found that the requested assignment would have no impact on the CCAA proceedings and would amount to unfair interference with the licensor's contractual rights. ${ }^{72}$

In addition, section 11.3(2) of the CCAA and section 84.1(3) of the BIA define specific agreements that may not be assigned. ${ }^{73}$ These include agreements entered into after proceedings are commenced under the CCAA or after the date of bankruptcy, eligible financial contracts (such as options and derivatives), collective agreements, certain financing agreements, and a lease of real property or an immovable where the debtor is the lessor.

Furthermore, a court may refuse to permit an assignment of rights and obligations that are "not assignable by reason of their nature." "4 Generally, this includes personal contracts such as a contract of employment. Quoting the Manitoba Court of Appeal in Black Hawk Mining

BIA, supra note 1 , s $84.1(4)$.

CCAA, supra note 3 , s $11.3(3)$.

Houlden, Morawetz \& Sarra, supra note 65 at 1364; Hayes Forest, supra note 64 at para 32.

(2009), 62 CBR (5th) 248 (Ont Sup Ct J) [Nexient Learning].

Ibid.

Ibid at 258 .

Ibid at 264.

CCAA, supra note 3, s 11.3(2); BIA, supra note 1, s 84.1(3).

Ford, supra note 63 at para 11 . 
Inc. v. Manitoba (Provincial Assessor), ${ }^{75}$ the Alberta Court of Appeal in Ford accepted the test for determining whether an agreement contains rights and obligations which by their nature are not assignable to be as follows: "Agreements are said to be personal in this sense when they are based on confidences, or considerations applicable to special personal characteristics, and so cannot be usefully performed to or by another." 76

\section{The Power of a Plan}

As described above, a plan of arrangement made under business corporations legislation, such as the $A B C A$ or the $C B C A$ can help corporations achieve certain business and economic outcomes to benefit their stakeholders that would be administratively more difficult to achieve under other corporate provisions. A plan of arrangement offers a flexible means of conveniently achieving a wide array of corporate reorganizations that may be proposed by a corporation and voted on by its shareholders. ${ }^{77}$ Once the corporation's shareholders have approved the plan, court approval must be obtained, and once this happens, the plan is binding upon the corporation and "all other persons," which includes counterparties to contracts. $^{78}$ It is an interesting question as to how far one can go in adjusting existing contractual rights.

The vague concept of fairness is at the centre of judicial discussion of when courts adjust the contractual rights of third parties to achieve a viable plan of arrangement. In Protiva Biotherapeutics Inc. v. Inex Pharmaceuticals Corp. ${ }^{79}$ Protiva Biotherapeutics Inc. (Protiva) appealed an order from the Supreme Court of British Columbia endorsing a plan of arrangement proposed by Inex Pharmaceuticals Corporation (Inex) to effectively transfer the assets and liabilities of Inex to Tekmira Pharmaceuticals Corporation (Tekmira). The result was that Inex's contractual obligations with Protiva went to Tekmira. ${ }^{80}$ Protiva objected because the assignment of the contracts at issue required Protiva's consent. ${ }^{81}$

The issue in the appeal was whether the trial Court erred in interpreting section 291(4)(c) of British Columbia's Business Corporations Act, ${ }^{82}$ as empowering the Court to make a discretionary order affecting contractual rights to ensure that the arrangement was fully carried out, and, in the alternative, whether it wrongly exercised its discretion. ${ }^{83}$

Protiva's main point regarding the first ground of appeal was that in order for a court to extinguish contractual rights, there must be clear language in a statute authorizing it to do so. The Court of Appeal disagreed, stating that no contract was being extinguished, and

2002 MBCA 51, [2002] 7 WWR 104 at para 82, citing Maloney v Campbell (1897), 28 SCR 228 at 233. Ford, supra note 63 at para 55.

Karen Carteri, "BC Courts Uphold Controversial Plan of Arrangement" (2008), McMillan LLP (blog), online: <www.mcmillan.ca/BC-Courts-Uphold-Controversial-Plan-of-Arrangement>.

ABCA, supra note 4 , s $193(9)$.

2007 BCCA 161, 280 DLR (4th) 704 [Protiva].

Ibid at para 1 .

Ibid.

SBC 2002, c 57, s 291(4)(c).

Protiva, supra note 79 at para 2. 
[i]n all material respects, Tekmira will be what Inex was, with the same personnel, balance sheet and undertaking, and bound to all the obligations under the contracts with Protiva. All that Protiva loses is the right to say 'no' to the assignment, an option the judge said was tantamount to a veto of the arrangement. ${ }^{84}$

Protiva was unsuccessful on the first ground of appeal, and in respect of the second, that the trial Court's discretion was inappropriately exercised, the Court of Appeal held that the lower Court's balancing of Protiva's right to withhold its consent against the overall benefit of the arrangement, including a potential benefit to Protiva, was not in error. ${ }^{85}$ The Court of Appeal categorically rejected the notion that "a proponent of an arrangement must be in extremis or otherwise show a public interest justification before third party contractual rights can be affected." ${ }^{86}$ The Court stated further that "[ $\left.\mathrm{t}\right]$ his would create a threshold requirement that finds no support in the legislation. Third party rights must be considered and accommodated within the discretionary analysis but they cannot be erected as an impermeable barrier to an arrangement." principle regarding the approval of arrangements that was articulated by the Supreme Court of Canada in respect of section 192 of the $C B C A,{ }^{88}$ namely, that it "focuses on whether the arrangement, objectively viewed, is fair and reasonable and looks primarily to the interests of the parties whose legal rights are being arranged." ${ }^{89}$ Further, when reviewing a "proposed arrangement to determine if it is fair and reasonable under s. 192, courts must be satisfied that (a) the arrangement has a valid business purpose, and (b) the objections of those whose legal rights are being arranged are being resolved in a fair and balanced way." 90

In Alberta, the courts have focused on the effect of arrangements on shareholders in determining whether the requirements for an arrangement have been met. In PetroKazakhstan Inc. v. Lukoil Overseas Kumkol B.V. ${ }^{91}$ (a decision involving section 193 of the $A B C A,{ }^{92}$ similar to the arrangement provision under section 192 of the $C B C A^{93}$ ), Lukoil Overseas Kumkol B.V. (Lukoil) objected to PetroKazakhstan Inc.'s (PetroKazakhstan) arrangement to facilitate a sale of all of PetroKazakhstan's outstanding shares. ${ }^{94}$ Lukoil asserted that its pre-emption rights in a shareholders' agreement with PetroKazakhstan would be affected (Lukoil and PetroKazakhstan each owned 50 percent of the shares in a third corporation). ${ }^{95}$ The shareholders' agreement included restrictions on assignment of the parties' interests, which Lukoil asserted would be breached if the arrangement was approved. ${ }^{96}$

Lukoil claimed this effect on its rights under the shareholders' agreement was contrary to law and established that the arrangement was not brought in good faith. However, the Court found that if it accepted Lukoil's position, the shareholders of PetroKazakhstan would be

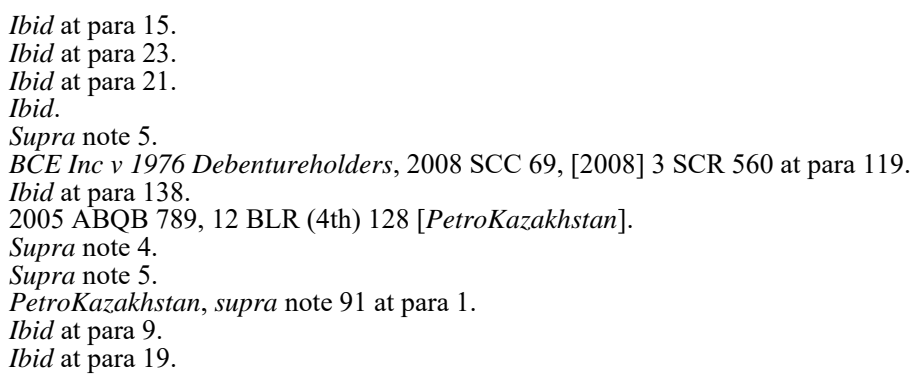


prejudiced as the deal would likely fall through. ${ }^{97}$ Lukoil was permitted to pursue its breach of contract claim through arbitration, and whether Lukoil succeeded would not impact the fairness of the arrangement to the PetroKazakhstan shareholders ${ }^{98}$ (it was an "all cash" deal so the shareholders would not be responsible for any future contractual liability). ${ }^{99}$ Furthermore, the argument that the Court would sanction a breach of contract by authorizing the arrangement presumed that the arrangement would breach the shareholders' agreement, an issue that was in dispute but not before the Court.

The Court was not willing to put the deal in jeopardy pending the uncertain outcome of Lukoil's breach of contract claim, especially since Lukoil's rights to pursue a remedy for the breach would not be affected by the arrangement. Therefore, despite the third party's claim that the arrangement breached a shareholders' agreement, the Court instead focused on the effect of the arrangement on the applicant's shareholders, and found that the requirements for an arrangement were met. ${ }^{100}$

The interpretation of the arrangement provisions in corporate legislation by courts in $\mathrm{BC}$ and Alberta has resulted in corporate lawyers using those provisions when rights under contracts are to be assigned and obtaining the consent of counterparties appears impractical. For example, several transactions where a corporation has monetized its tax losses have involved: (1) transferring nearly all of the assets and liabilities of the corporation to a newly incorporated entity having the same shareholders, directors, and officers as the corporation; and (2) transferring the shares of the corporation to a third party wishing to acquire the company's tax characteristics. As is typically the case for oil and gas companies, the asset transfer is practically difficult to implement as the assets include numerous (sometimes hundreds or thousands) of contracts, with various types of provisions speaking to assignment. Typically, some of those provisions require consent which can be arbitrarily withheld, and some require consent which cannot be unreasonably withheld. By using the arrangement provisions which refer to the division of the business carried on by a corporation ${ }^{101}$ and providing a simple notice to all of the counterparties, each of the contracts can be assigned once the court issues its final order approving the arrangement, which is binding on not only the corporation and its shareholders but on all other persons, including the contract counterparties. This approach is far superior, from a practical perspective, than attempting to obtain all of the necessary consents under the strict terms of the contracts. The approach is particularly appealing for non-controversial situations where, from an objective business perspective, no contract counterparts ought to object to the assignment.

In situations where the contract counterparts might well have a reasonable objection to the assignment, the use of a corporate plan of arrangement might nonetheless be successful. As described above, courts will consider the larger picture and are loathe to find that, in effect, a third party has a veto over a reorganization that benefits stakeholders generally. From the perspective of a contract counterparty, the court's position might well seem like a failure to honour the deal that the counterparty bargained for when the contract was negotiated. This raises the obvious question of whether protections against this outcome can be negotiated at 
the time the contract is signed. For example, could a covenant be included that the corporation will not propose a plan of arrangement that results in the contract counterparty losing any rights or privileges it has under the terms of the contract, and could injunctive relief be obtained preventing the company from seeking court approval for a plan of arrangement that breaches the covenant? Perhaps, but will the court view such measures as an undue interference with the court's general discretion under the corporate arrangement provisions to approve a reorganization seen to be in the best interests of all stakeholders? If the court is willing to override non-assignment provisions in the contract, why would any specific covenant be treated differently? Arguably the only enforceable protection available might be liquidated damages for breach of the covenant, presuming the court does not view the payment of the damages as, given the particular circumstances, an effective veto over the reorganization under the plan of arrangement.

\section{CONCLUSION}

As a consequence of reduced commodity prices, and in the context of a number of high profile insolvencies, parties in the energy industry are increasingly concerned about the impact a counterparty insolvency might have on contracts material to their businesses. Insolvency law clearly permits contracts to be terminated or assigned without consent, or can result in certain contractual provisions being unenforceable. Such risks should be taken into account in the overall assessment of counterparty risk and credit risk management strategies. But having regard for the overall policy considerations that support this legal regime, the industry's collective interest in ensuring the maximization of resources available to an insolvent party and its creditors, and the ability of parties to structure their arrangements so as to efficiently allocate and manage these risks, this legal structure seems ultimately wellfounded, notwithstanding the periodic unfairness viewed from the perspective of a singular adversely affected counterparty.

From the solvent party's perspective, insolvency law can have significant effects on terms that were bargained and paid for by a counterparty, and an unsecured claim may have little value. It is not always easy to achieve a balance between achieving restructuring or insolvency objectives and preserving legitimate bargains. Yet parties are not without legal tools to address these risks. Increasingly sophisticated counterparty credit risk assessment tools, coupled with conventional security interests and other credit risk mitigation measures, allow parties to a transaction to assess and manage the consequences of insolvency law.

The importance of understanding the law in this area, the breadth of a court's authority under insolvency law and in connection with plans of arrangement, and strategies for managing the attendant risks resulting from this legal landscape, has never been as important to energy practitioners. Increasingly, borrowers, lenders, and counterparties are approaching these issues with greater sophistication and nuance, relying less on traditional covenants and security interests, and more on context- and risk-specific measures, to ensure the most efficient allocation of opportunities and risks. All of this requires a more complete understanding of the law and policy considerations underlying insolvency in the energy industry. 